\title{
The Influence Of Customers' Perception And Attitudes Toward Customer Purchase Intention At Gramedia Lembuswana, Samarinda
}

\author{
Hanif Adinugroho Widyanto ${ }^{1}$ Tubagus Achmad Rachmad Saleh ${ }^{2}$ \\ ${ }^{1}$ Management, Faculty of Business, President University, Cikarang, Indonesia \\ ${ }^{2}$ Management, Faculty of Business, President University, Cikarang, Indonesia \\ ${ }^{1}$ Email: hanif@president.ac.id \\ ${ }^{2}$ Email: tubagus96@gmail.com
}

\begin{abstract}
This research aims to find out the influence between customers' perceptions and attitude toward customer purchase intention at Gramedia Lembuswana, Samarinda that is experiencing a slowdown in sales growth. Factors examined are extrinsic factors which include perceived price, advertisement, and store image; intrinsic factors which include perceived quality, perceived risk and perceived value; and customer' attitudes which include trust, and familiarity. All responses were collected by using questionnaire with a purposive sampling method. The methodology used in this research is quantitative by utilizing the multiple regression analysis. The research population are people who have purchased items at Gramedia Lembuswana. Likert scale was used on 165 random respondents of the research. The result shows that perceived value, advertisement, store image, trust, and familiarity have significant influence toward intention to purchase, while perceived quality, perceived risk, and perceived price do not have a significant influence toward customer purchase intention. Finally, all the independent variables are found to have simultaneously significant impact toward customer purchase intention with an adjusted R square value of 0.467 .
\end{abstract}

Keywords: Customers' perceptions, intrinsic factor, extrinsic factor, attitude

\begin{abstract}
Abstrak
Penelitian ini bertujuan untuk mengetahui pengaruh antara persepsi dan sikap pelanggan terhadap minat beli pelanggan di Gramedia Lembuswana, Samarinda yang mengalami perlambatan pertumbuhan penjualan. Faktor-faktor yang diperiksa adalah faktor-faktor ekstrinsik yang meliputi harga yang dirasakan, iklan, dan citra toko; faktor intrinsik yang meliputi kualitas yang dirasakan, risiko yang dirasakan dan nilai yang dirasakan; dan sikap pelanggan yang mencakup kepercayaan, dan keakraban. Semua tanggapan dikumpulkan dengan menggunakan kuesioner dengan metode purposive sampling. Metodologi yang digunakan dalam penelitian ini adalah kuantitatif dengan memanfaatkan analisis regresi berganda. Populasi penelitian adalah orang yang telah membeli barang di Gramedia Lembuswana. Skala likert digunakan pada 165 responden acak dari penelitian. Hasilnya menunjukkan bahwa nilai yang dirasakan, iklan, citra toko, kepercayaan, dan keakraban memiliki pengaruh yang signifikan terhadap niat untuk membeli, sedangkan kualitas yang dirasakan, risiko yang dirasakan, dan harga yang dirasakan tidak memiliki pengaruh yang signifikan terhadap niat pembelian pelanggan. Akhirnya, semua variabel independen ditemukan memiliki dampak signifikan secara simultan terhadap niat pembelian pelanggan dengan nilai $\mathrm{R}$ square yang disesuaikan sebesar 0,467 .
\end{abstract}

Kata kunci: Persepsi pelanggan, faktor intrinsik, faktor ekstrinsik, sikap 


\section{INTRODUCTION}

The transformative power of information technology has moved our society forward and accelerated the transition process of civilization, supported by the swift flow of information, which in turn forced people to have the ability and extensive knowledge to survive the digital era. Specifically, the dawn of the Internet has allowed people to search for a virtually unlimited amount of information needed (Muslim, 2011). This phenomenon also applies to the way people consume books, especially with the introduction and rise of e-book which has revolutionized the industry (Yalman, 2014).

Unfortunately, the proliferation of e-book has forced a lot of traditional publishers and bookstores to declare bankruptcy. In Indonesia alone, there were around 5,000 bookstores countrywide back in 2005, but a decade later, there were only about 1,000 bookstores left (Rahadi, 2015). Amid the current digital onslaught, Gramedia, the largest bookstore chain in Indonesia, still manages to survive by constantly changing their concept to suit customer's needs, which has turned them beyond just a simple bookstore. However, challenges still abound for the company, and some of its most promising branches, such as Gramedia Lembuswana in Samarinda, East Kalimantan, which was ranked fourth in terms of sales growth in 2016 at $11 \%$ (the best performing branch outside of Java island), suffered a significant downturn during the calendar year 2017, with a meagre sales growth of $1 \%$ (Gramedia, 2018).

This rapidly declining rate meant that a huge portion of visitors who came to Gramedia Lembuswana did not make a purchase. The considerable number of visitors who did not make a purchase could be caused by various factors, such as window shopping, price comparison, or reduced buying power, and among other possible reasons. This prompts the researchers to look into the possible factors influencing purchase intention at Gramedia Lembuswana. Specifically, the researchers will adopt a previous study by Jaafar et al. (2015) which studies the influence of perceived price, store image, advertisement, perceived quality, perceived risk, perceived value, trust, and familiarity toward customers' purchase intention.

\section{Literature Review}

\subsection{Purchase intention}

Purchase intention is defined as customers' basic decision-making based on the motivation to purchase a certain brand (Shah et al., 2012). Mirabi et al. (2015) characterized purchase intention as a circumstance wherein customer tends to purchase a specific good in a particular condition. Customer purchase decision is an extremely complex process. Purchase intention is commonly identified and relevant to the behavior, perceptions, and attitudes of buyers.

\subsection{Factors Influencing Purchase Intention}

There have been a huge amount of studies regarding factors influencing customer purchase intention. However, most of the research undertaken on the topic are revolving around goods, and less on services, particularly on retail business (Milfelner et al., 2011). A study conducted by 
Chaniotakis et al. (2010) found that the factors influencing consumer's purchase intention include consumers' attitudes, extrinsic factors, and intrinsic factors.

\subsection{Consumers' Attitudes}

Consumer attitudes is described as a favorable or unfavorable feeling derived from the evaluation of an object, such as product or service offerings, brands, prices, stores, etc. According to Schiffman and Kanuk (2007), consumer attitude is an educated predisposition to behave consistently good or unfavorable based on feelings and opinions resulting from the evaluation of knowledge about the object. Consumer attitudes play an important role in influencing consumer buying intentions. Chaniotakis et al. (2010) argued that the 'way of thinking' influence consumers' buying intentions.

\subsubsection{Trust}

Trust is often defined as the general expectation of individual belief in the words of others and considered as an important factor for purchase intention. The degree to which a person holds fast, and expects on the words, actions, and decisions of others and the uniqueness of the actions of the consumer has resulted in the willingness of the average consumer to expect certain benefits of the brand being displayed (Reast, 2005). Trust dimensions have been centered on factors such as brand trust, trusted product, customer needs fulfillment, and service quality. Hence, the following hypothesis is proposed:

H1. There is a significant influence of trust toward customer purchase intention.

\subsubsection{Familiarity}

Brand familiarity can be defined as the level of experience directly or indirectly to the consumer of a product or brand (Dursun et al., 2011). So that brand familiarity can also be interpreted how familiar consumers to a brand. The consumer's knowledge of a well-known brand is characterized by a higher structured association compared to their knowledge of lesserknown brands.

Dursun et al. (2011) explained that the more familiar brands have a more theoretical capacity needed to process the associations related to an earlier trademark, and consequently fewer resources are available to process new information. Khasawneh and Hasouneh (2010) found that consumers really consider the brand as an important signal to the name of the product and making their purchasing decisions, they value products with brands they already familiar with. Consumers tend to agree that the product is more reliable and has a better quality than any other product without a brand name or with an unknown brand name. According to Ha (2004), familiarity with a company or brand can result in higher trust, unless the consumer has a negative perception of the brand. Thus, brand familiarity has an important role in purchase intention. Familiarity have also been centered on factors such as shopping frequency, brand knowledge, and experience. Consistent with these findings, it is hypothesized that:

H2. There is a significant influence of familiarity toward customer purchase intention. 


\subsection{Extrinsic Factors of the Product}

Extrinsic is defined as the state of not being an inherent part of the thing or not contained in something (Free Dictionary, 2011). Past research has shown that extrinsic cues play an important role in influencing consumers' purchase intention than intrinsic cues (Richardson, 1997). A research by Jaafar et al. (2015) stated that extrinsic factors of the product are perceived price, store image, and advertisement.

\subsubsection{Perceived Price}

According to Wang \& Chen (2016), perceived price is a consumer's perceptions of price, which includes sacrificed money, time cost, search cost, effort, and psychic costs. According to Tsai and Lee (2007), perceived price indicates consumer's sensitivity to price variations. Suter and Hardesty (2005) found that someone with a greater price perception is depicted less willing to buy the product. Perceived price dimensions have been centered on factors such as the importance of price, price comparison, and reasonable price. Thus, the researchers hypothesized that:

H3. There is a significant influence of perceived price toward customer purchase intention.

\subsubsection{Store Image}

Store image is defined as a set of brand associations linked to the store in the consumer's memory. Brand associations are concerned both with perceptions of the store attributes and the consumer's perceived benefits. Store image dimensions have been centered on factors such as the

quality and variety of the products sold, the prices of the products, physical facilities of the store, and the services provided by sales personnel (Erdil, 2015).

Schiffman and Kanuk (2007) found that stores or outlets have the image of the store or the company itself that helps influence the perceived quality and consumer decisions regarding product purchases. Meanwhile, according to Simamora (2003), store image is considered as one of the most valuable assets for a business. Just like a product, a store also has its own personality, which represents a complete picture of the retailer for consumers. Therefore, retailers should be able to know and design the store in such a way that they want consumers to see and feel. Consistent with these findings, we propose that:

H4. There is a significant influence of store image toward customer purchase intention.

\subsubsection{Advertisement}

Purchase intention can be influenced by advertising, which is formed by creating awareness, providing product information, and helping consumers determine the value and quality of the product and assisting them to make the best purchasing choices (Kotler \& Armstrong, 2012). Advertisement can be divided into four dimensions namely product information, decision making, in-store ads, and advertisement message. Consequently, we pose the following research hypotheses: 
H5. There is a significant influence of advertisement toward customer purchase intention.

\subsection{Intrinsic Factors of the Product}

Intrinsic is defined as being a natural part of something (Oxford Dictionaries, 2018). As stated by Jaafar et al. (2015), intrinsic factor includes perceived quality, perceived risk, and perceived value.

\subsubsection{Perceived Quality}

Perceived quality is the customers' sense of product or service quality and features that give them the performance and reliability of such products. Promises made by brand products to meet customer expectations (Erdoğmuş \& Büdeyri-Turan, 2012). An important factor influencing customer purchase intention is perceived quality. Tsiotsou (2005) research shows the existence of a causal relationship model in which perceived quality perceptions influence consumer purchase intentions. Tsiotsou (2005) divided perceived quality into three dimensions; product criterion, the importance of high-quality products, and expectations. Similar to the findings, we propose that:

H6. There is a significant influence of perceived quality toward customer purchase intention.

\subsubsection{Perceived Risk}

Perceived risk can be interpreted as the consequences that will always follow every consumer action and can tend to be unpleasant. Perceived risk is an important factor in influencing consumer buying intention. Perceived risk can occur because of uncertainty about the capabilities of the product and the product may not have the attributes that have been promised (Wang \& Chen, 2016). The greater the perceived risk, the lower it is for purchase intention to develop toward products or services (Cho, 2010). Wang and Chen (2016) divided perceived risk into three dimensions, which include physi ological risk, financial risk, and functional risk. Hence, we pose the following hypothesis:

H7. There is a significant influence of perceived risk toward customer purchase intention.

\subsubsection{Perceived Value}

Perceived value is the difference between the prospective customers' assessment of all the benefits and costs of an offer against its alternatives (Kotler \& Keller, 2008). Today, customers are more educated and knowledgeable. Consumers' perceptions of value represent a trade-off between the perceived quality or benefits in the product relative to the perceived sacrifice by paying the price. Perceived value dimensions have been centered on factor such as cost, mobility, and preferable brand. Thus, we present the following hypothesis:

H8. There is a significant influence of perceived value toward customer purchase intention. 
Theoretical Framework

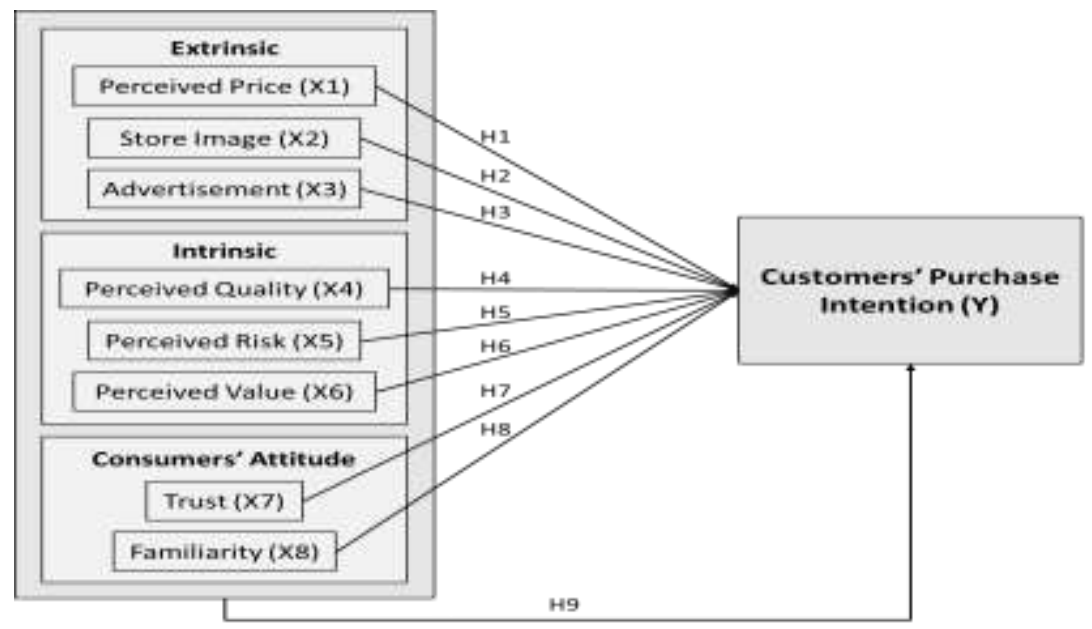

Figure 1. Theoretical Framework

Adapted from Jaafar et al. (2015)

\section{METHODOLOGY}

The population of this research is people who have purchased a product from Gramedia Lembuswana, Samarinda. The researchers used a questionnaire with Likert scale as the primary tool to collect the data and the questions are based on the predetermined variables adapted from Jaafar et al (2015). The questionnaires were distributed between January $1^{\text {st }}, 2018$ and January $20^{\text {th }}, 2018$ by means of the Google Form. Finally, the researchers used the non-probability sampling method of purposive sampling technique on a total of 165 respondents. 


\section{Analysis}

4.1. Multiple Regression Analysis

\begin{tabular}{|c|c|c|c|c|c|}
\hline \multirow{4}{*}{ Model } & \multicolumn{3}{|c|}{ Coefficients $^{\mathrm{a}}$} & \multirow{4}{*}{$\mathrm{t}$} & \multirow{4}{*}{ Sig. } \\
\hline & \multirow{2}{*}{\multicolumn{2}{|c|}{$\begin{array}{l}\text { Unstandardized } \\
\text { Coefficients }\end{array}$}} & \multirow{2}{*}{$\begin{array}{l}\text { Standardized } \\
\text { Coefficients }\end{array}$} & & \\
\hline & & & & & \\
\hline & $\mathrm{B}$ & Std. Error & Beta & & \\
\hline (Constant) & .261 & .367 & & .712 & .478 \\
\hline Perceived Quality & -.014 & .072 & -.013 & -.187 & .852 \\
\hline Perceived Risk & -.010 & .074 & -.008 & -.134 & .894 \\
\hline Perceived Value & .300 & .084 & .293 & 3.555 & .000 \\
\hline Perceived Price & -.103 & .064 & -.112 & -1.611 & .109 \\
\hline Advertisement & .174 & .055 & .205 & 3.171 & .000 \\
\hline Store Image & .387 & .100 & .349 & 3.868 & .000 \\
\hline Trust & .447 & .084 & .410 & 5.299 & .000 \\
\hline Familiarity & .124 & .062 & .129 & 2.014 & .046 \\
\hline
\end{tabular}

a. Dependent Variable: Customer Purchase Intention

From the result in Table 1, in the unstandardized form of the equation, the regression model is as follows:

$Y=0.261+0.300 X_{3}+0.174 X_{5}+0.387 X_{6}+0.447 X_{7}+0.124 X_{8}$

Where;

$\mathrm{Y}=$ Customer purchase intention

$\mathrm{X}_{3}=$ Perceived value

$\mathrm{X}_{5}=$ Advertisement

$\mathrm{X}_{6}=$ Store Image

$\mathrm{X}_{7}=$ Trust

$\mathrm{X}_{8}=$ Familiarity 
According to this equation result, the interpretation of multiple regressions stated as follows:

1. Constant (a): 0.261 , the value of constant is positive means if the value of variables $\mathrm{X}_{1}, \mathrm{X}_{2}, \mathrm{X}_{3}, \mathrm{X}_{4}, \mathrm{X}_{5}, \mathrm{X}_{6}, \mathrm{X}_{7}, \mathrm{X}_{8}$ are considered none or equal to 0 then the $\mathrm{Y}$ value is 0.261 .

2. Perceived value $\left(\mathrm{X}_{3}\right)$ variable has multiple linear regression value of 0.300 which it shows that every increasing one point in perceived value variable will be influencing to the increase of purchase intention value as many as 0.300 point.

3. Advertisement $\left(\mathrm{X}_{5}\right)$ variable has a multiple linear regression value of 0.174 which it shows that every increasing one point in advertisement variable will be influencing to the increase of purchase intention value as many as 0.174 point.

4. Store image $\left(\mathrm{X}_{6}\right)$ variable has a multiple linear regression value of 0.387 which it shows that every increasing one point in store image variable will be influencing to the increase of purchase intention value as many as 0.387 point.

5. Trust $\left(\mathrm{X}_{7}\right)$ variable has a multiple linear regression value of 0.447 which it shows that every increasing one point in trust variable will be influencing to the increase of purchase intention value as many as 0.447 point.

6. Familiarity $\left(\mathrm{X}_{8}\right)$ variable has a multiple linear regression value of 0.124 which it shows that every increasing one point in familiarity variable will be influencing to the increase of purchase intention value as many as 0.124 point.

\subsection{T-test}

T-Test is used to define whether each independent variable has partial significant influences toward the dependent variable or not. T-table with a score of 1.65 was used. If the $t$ value > t table, then $\mathrm{H}_{\mathrm{o}}$ would be rejected, and $\mathrm{H}_{\mathrm{a}}$ accepted. On the other hand, if $\mathrm{t}$ value $<\mathrm{t}$ table, then $\mathrm{H}_{\mathrm{o}}$ would be accepted, and $\mathrm{H}_{\mathrm{a}}$ rejected.

Table 1 shows the significant value of each variable. The individual results for each variable are as follow:

1. Perceived quality $\left(\mathrm{X}_{1}\right)$ toward purchase intention $(\mathrm{Y})$

$\mathrm{H}_{\mathrm{o} \cdot 1}: \beta_{1}=0$ : There is no significant influence of perceived quality toward customer purchase intention.

$\mathrm{H}_{\mathrm{a} \cdot 1}: \beta_{1} \neq 0$ : There is a significant influence of perceived quality toward customer purchase intention

It can be seen from Table 1 that perceived quality has a $t$ value of -0.187 . The $t$ value smaller than $\mathrm{t}$ table at 1.65 , which means that perceived quality has no significant influence toward customer purchase intention at Gramedia Lembuswana. $\mathrm{H}_{0 \cdot 1}$ is accepted and $\mathrm{H}_{\mathrm{a} .1}$ is rejected in hypothesis 1 .

2. Perceived risk (X2) toward purchase intention (Y)

$\mathrm{H}_{\mathrm{o} .2}: \beta 2=0$ : There is no significant influence of perceived risk toward customer purchase intention.

$\mathrm{H}_{\mathrm{a} .2}: \beta 2 \neq 0$ : There is a significant influence of perceived risk toward customer purchase intention. 
It can be seen from Table 1 that perceived risk has a $t$ value of -0.134 . The $t$ value is smaller than t table at 1.65 , which means that perceived risk has no significant influence toward customer purchase intention at Gramedia Lembuswana. Hence, $\mathrm{H}_{0.2}$ is accepted and $\mathrm{H}_{\mathrm{a} .2}$ is rejected in hypothesis 2 .

3. Perceived value (X3) toward purchase intention (Y)

$\mathrm{H}_{0.3}: \beta 3=0$ : There is no significant influence of perceived value toward customer purchase intention.

$\mathrm{H}_{\mathrm{a} .3}: \beta 3 \neq 0$ : There is a significant influence of perceived value toward customer purchase intention.

It can be seen from the table 1 that perceived value has a $t$ value of 3.555 . The $t$ value is larger than $t$ table at 1.65 , which means perceived value has a significant influence toward customer purchase intention at Gramedia Lembuswana. Hence, $\mathrm{H}_{\mathrm{o} .3}$ is rejected and $\mathrm{H}_{\mathrm{a} .3}$ is accepted in hypothesis 3 .

4. Perceived price $(\mathrm{X} 4)$ toward purchase intention $(\mathrm{Y})$

$\mathrm{H}_{0.4}: \beta 4=0$ : There is no significant influence of perceived price toward customer purchase intention.

$\mathrm{H}_{\mathrm{a} .4:} \beta 4 \neq 0$ : There is a significant influence of perceived price toward customer purchase intention.

It can be seen from Table 1 that perceived price has a $t$ value of -1.611 . The $t$ value is smaller than the t table at 1.65 , which means perceived price has no significant influence toward customer purchase intention at Gramedia Lembuswana. Hence, $\mathrm{H}_{0.4}$ is accepted and $\mathrm{H}_{\mathrm{a} .4}$ is rejected in hypothesis 4 .

5. Advertisement (X5) toward purchase intention (Y)

$\mathrm{H}_{\mathrm{o.5}}: \beta 5=0$ : There is no significant influence of advertisement toward customer purchase intention.

$\mathrm{H}_{\mathrm{a} .5}: \beta 5 \neq 0$ : There is a significant influence of advertisement toward customer purchase intention.

It can be seen from Table 1 that advertisement has a t value of 3.171. The $t$ value is more than the $\mathrm{t}$ table at 1.65, which means advertisement has a significant influence toward customer purchase intention at Gramedia Lembuswana. Hence, $\mathrm{H}_{\mathrm{o.5}}$ is rejected and $\mathrm{H}_{\mathrm{a} .5}$ is accepted in hypothesis 5 .

6. Store image (X6) toward purchase intention (Y)

$\mathrm{H}_{0.6}: \beta 6=0$ : There is no significant influence of store image toward customer purchase intention.

$\mathrm{H}_{\mathrm{a} .6}: \beta 6 \neq 0$ : There is a significant influence of Store image toward customer purchase intention.

It can be seen from Table 1 that store image has a $t$ value of 3.868. The $t$ value is larger than the $\mathrm{t}$ table at 1.65, which means store image has a significant influence toward customer purchase intention at Gramedia Lembuswana. Hence, $\mathrm{H}_{\mathrm{o.} 6}$ is rejected and $\mathrm{H}_{\mathrm{a} .6}$ is accepted in hypothesis 6.

7. Trust (X7) toward purchase intention (Y)

$\mathrm{H}_{0.7}: \beta 7=0$ : There is no significant influence of trust toward customer purchase intention. 
$H_{a .7}: \beta 7 \neq 0$ : There is a significant influence of trust toward customer purchase intention.

It can be seen from Table 1 that trust has a $t$ value of 5.299. The $t$ value is larger than $t$ table at 1.65, which means trust has a significant influence toward customer purchase intention at Gramedia Lembuswana. Hence, $\mathrm{H}_{0.7}$ is rejected and $\mathrm{H}_{\mathrm{a} .7}$ is accepted in hypothesis 7 .

8. Familiarity (X8) toward purchase intention $(\mathrm{Y})$

$\mathrm{H}_{0.8}: \beta 8=0$ : There is no significant influence of familiarity toward customer purchase intention.

$\mathrm{H}_{\mathrm{a} .8}: \beta 8 \neq 0$ : There is a significant influence of familiarity toward customer purchase intention.

It can be seen from Table 1 that familiarity has a $T$ value of 2.014. The $t$ value is larger than the $\mathrm{t}$ table at 1.65 , which means familiarity has a significant influence toward customer purchase intention at Gramedia Lembuswana. Hence, $\mathrm{H}_{\mathrm{o} .8}$ is rejected and $\mathrm{H}_{\mathrm{a} .8}$ is accepted in hypothesis 8 .

\subsection{F-test}

F- Test is also used to evaluate the simultaneous effect of all independent variables toward the dependent variable. The independent variable consists of perceived quality, perceived risk, perceived value, perceived price, advertisement, store image, trust, and familiarity. This method is used to measure if there are any significant effects between the independent and dependent variables. If the $\mathrm{F}$ value $>\mathrm{F}$ table, then Ho.9 is rejected and $\mathrm{H}_{\mathrm{a} \cdot 9}$ is accepted. Conversely, if $\mathrm{F}$ value < F table, then Ho.g is accepted and Ha.9 is rejected.

\section{Table 2. F-Test Result}

\begin{tabular}{|c|c|c|c|c|c|c|}
\hline \multicolumn{7}{|c|}{ ANOVA $^{a}$} \\
\hline Model & & $\begin{array}{l}\text { Sum } \\
\text { Squares }\end{array}$ & of $\mathrm{df}$ & Mean Square & $\mathrm{F}$ & Sig. \\
\hline \multirow{3}{*}{1} & Regression & 49.625 & 8 & 6.203 & 18.978 & $.000^{b}$ \\
\hline & Residual & 50.990 & 156 & .327 & & \\
\hline & Total & 100.616 & 164 & & & \\
\hline
\end{tabular}

a. Dependent Variable: Purchase Intention

b. Predictors: (Constant), Familiarity, Perceived Risk, Advertisement, Store Image, Perceived Quality, Perceived price, Perceived Value, Trust

Hypothesis:

Ho.9: $\beta_{1}=\beta_{2}=\beta_{3}=\beta_{4}=\beta_{5}=\beta_{6}=\beta_{7}=\beta_{8}=\beta_{9}=0$ : Perceived quality, perceived risk, perceived value, perceived price, advertisement, store image, trust, and familiarity have no simultaneously significant influence toward customer purchase intention.

$\mathrm{H}_{\mathrm{a} .9}$ : at least $\beta_{1} \neq 0$ : Perceived quality, perceived risk, perceived value, perceived price, advertisement, store image, trust, and familiarity have a simultaneously significant influence toward customer purchase intention.

In this case, $\mathrm{F}$ value $>\mathrm{F}$ table, $18.978>2.00$, df $1=8$, df $2=156$ and the significant value must be less than 0.05 . It can be seen from Table 2 that the number of significant value is 
0.000. Since the significant value is less than 0.05 , this means that all independent variables that consist of perceived quality, perceived risk, perceived value, perceived price, advertisement, store image, trust, and familiarity have a simultaneously significant influence toward purchase intention. From the hypothesis we can conclude that $\mathrm{H}_{\mathrm{a} \cdot 9}$ is accepted and the $\mathrm{H}_{\mathrm{o} .9}$ rejected.

\subsection{Coefficient of Determination $\left(\mathbf{R}^{2}\right)$}

The coefficient of determination $\left(\mathrm{R}^{2}\right)$ essentially measures how much can the model explain the variations in the dependent variable. The coefficient of determination is between zero and one, which can be observed in Table 3 below:

Table 3. Coefficient Determination $\left(\mathbf{R}^{2}\right)$

\begin{tabular}{|c|c|c|c|c|c|}
\hline \multicolumn{6}{|c|}{ Model Summary } \\
\hline Model & $\mathrm{R}$ & R Square & $\begin{array}{l}\text { Adjusted } \\
\text { Square }\end{array}$ & $\begin{array}{l}\mathrm{R} \text { Std. Error of the } \\
\text { Estimate }\end{array}$ & Durbin-Watson \\
\hline$\overline{1}$ & $.702^{\mathrm{a}}$ & .493 & .467 & .571 & 2.098 \\
\hline
\end{tabular}

According to Noor (2015), for a regression model with more than 2 independent variables, it is more advisable to use the adjusted $\mathrm{R}$ square value as the coefficient of determination. Based on Table 3, it can be seen that the value of $R$ is 0.702 , which means that there is a correlation between the independent variables and purchase intention. For the adjusted $\mathrm{R}$ square value of 0.467 , it can be inferred that the independent variables can explain $46.7 \%$ of the variations in the dependent variable, while the remaining $53.3 \%$ are influenced by other factors.

\section{Conclusion and recommendation}

This study aims to determine whether there is influence between consumer's perception and attitude toward customer purchase intention at Gramedia Lembuswana. Based on the results and discussion in this research, it can be concluded that perceived value, advertisement, store image, trust and familiarity significantly influence purchase intention. This indicates that the management of Gramedia Lembuswana Samarinda should be focusing on improving their perceived value, advertisement, store image, trust, and familiarity. Based on the results of the study, the management is advised to put more emphasis on in-store advertisements and messages within the ads. Furthermore, they should also improve the shopping experience, increase product variety, and focus on the product layout, by providing surprise and delighting the customers. They should also deliver beyond customer's expectation by providing additional values and trust, evaluating and resolving any feedbacks from customer, and ensuring competent staff members through training and evaluation.

Based on the results of this research, there are several suggestions future research. First, there should be a research on companies in book retail industry since the book retail industry is facing a digital onslaught which makes its derivative businesses failing. Second, future 
research could also examine the other variables related to the purchase intention. Finally, it is advisable to use samples from several different studies in order to observe the different effects between sample groups.

\section{References}

\section{Corporate data:}

Gramedia (2018). Internal Gramedia Data for Sales Growth of Regional 8.

\section{Books:}

Kotler, P. \& Armstrong, G. (2012), Principles of Marketing (13th Edition). New Jersey: Pearson Prentice Hall.

Kotler, P., \& Keller, K. L. (2008). Marketing Management (13th Edition). New Jersey: Prentice Hall.

Noor, Juliansyah (2015). Analisis Data Penelitian Ekonomi \& Manajemen. Jakarta: Grasindo.

Schiffman, L. G., \& Kanuk, L. L. (2007). Consumer Behavior (9th Edition). New Jersey: Prentice Hall.

Simamora, Bilson. (2003). Membongkar Kotak Hitam Konsumen. Jakarta: PT Gramedia Pustaka.

\section{Journal Articles:}

Chaniotakis, I. E., Lymperopoulos, C., \& Soureli, M. (2010). Consumers' intentions of buying own-label premium food products. Journal of Product \& Brand Management, 19(5), 327-334. https://doi.org/10.1108/10610421011068568

Cho, S. E. (2010). Perceived risks and customer needs of geographical accessibility in electronic commerce. Electronic Commerce Research and Applications, 9(6), 495-506. https://doi.org/10.1016/j.elerap.2010.02.005

Dursun, I., Kabadayi, E. T., Alan, A. K., \& Sezen, B. (2011). Store brand purchase intention: Effects of risk, quality, familiarity and store brand shelf space. Procedia - Social and Behavioral Sciences, 24, 1190-1200. https://doi.org/10.1016/j.sbspro.2011.09.133

Erdil, T. S. (2015). Effects of Customer Brand Perceptions on Store Image and Purchase Intention: An Application in Apparel Clothing. Procedia - Social and Behavioral Sciences, 207, 196-205. https://doi.org/10.1016/j.sbspro.2015.10.088

Erdoğmuş, İ., \& Büdeyri-Turan, I. (2012). The role of personality congruence, perceived quality and prestige on ready-to-wear brand loyalty. Journal of Fashion Marketing and Management: An International Journal, 16(4), 399-417. https://doi.org/10.1108/13612021211265818

Ha, H. (2004). Factors influencing consumer perceptions of brand trust online. Journal of $\begin{array}{lll}\text { Product } \quad \text { B } & \text { Management, } & \text { 13(5), 329-342. }\end{array}$ 
https://doi.org/10.1108/10610420410554412

Jaafar, S. N., Lalp, P. E., \& Mohamed, M. (2015). Consumers' Perceptions, Attitudes and Purchase Intention toward Private Label Food Products in Malaysia. Asian Journal of Business and Management Sciences, 2(8), 73-90.

Milfelner, B., Snoj, B., \& Korda, A. P. (2011). Measurement of Perceived Quality, Perceived Value, Image, and Satisfaction Interrelations of Hotel Services: Comparison of Tourists from Slovenia and Italy. Drustvena Istrazivanja, $20(3$ (113)), 602-624. https://doi.org/10.5559/di.20.3.01

Mirabi, V., Akbariyeh, H., \& Tahmasebifard, H. (2015). A Study of Factors Affecting on Customers Purchase Intention Case Study: the Agencies of Bono Brand Tile in Tehran. Journal of Multidisciplinary Engineering Science and Technology (JMEST), 2(1), 267273. https://doi.org/10.1017/CBO9781107415324.004

Reast, J. D. (2005). Brand trust and brand extension acceptance: the relationship. Journal of Product \& Brand Management, 14(1), 4-13. https://doi.org/10.1108/10610420510583707

Richardson, P. S. (1997). Are store brands perceived to be just another brand? Journal of

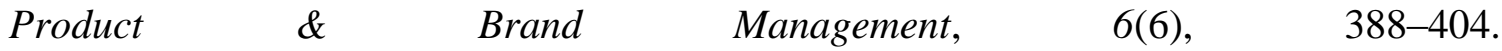
https://doi.org/10.1108/10610429710190432

Shah, Syed Saad Hussain, Aziz, Jabran, Jaffari, Ahsan Raza, Waris, Sidra, Ejaz, Wasiq, Fatima, Maira, \& Sherazi, S. K., Aziz, J., Jaffari, A. R., Waris, S., Ejaz, W., Fatima, M., $\&$ Sherazi, S. K. (2012). The Impact of Brands on Consumer Purchase Intentions. Asian Journal of Business Management, 4(2), 105-110. Retrieved from http://maxwellsci.com/print/ajbm/v4-105-110.pdf

Tsai, D., \& Lee, H. (2007). Will you care when you pay more? The negative side of targeted promotions. Journal of Product \& Brand Management, 16(7), 481-491. https://doi.org/10.1108/10610420710834931

Tsiotsou, R. (2005). Perceived Quality Levels and their Relation to Involvement, Satisfaction, and Purchase Intentions. Marketing Bulletin, (Research Note 4), 1-10. Retrieved from http://marketing-bulletin.massey.ac.nz/V16/MB_V16_N4_Tsiotsou.pdf

Wang, Y., \& Chen, L.-Y. (2016). An Empirical Study of the Effect of Green Marketing on Purchase Intention - Evidence from Green Restaurant. Advances in Management and Applied Economics, 6(4), 1-14.

Yalman, Murat (2014). Preservice teachers' view about e-book and their level of use of ebooks. Procedia - Social and Behavioral Sciences, 176, 255-262.

\section{Thesis, Dissertation:}

Muslim, M. I. (2011). Analisis Pengaruh Merchandise, Promosi, Atmosfer Dalam Gerai, Pelayanan Ritel, dan Harga Terhadap Keputusan Pembelian (Studi Pada Toko Buku Gramedia Pandanaran Kota Semarang). Universitas Diponegoro.

\section{Websites:}

Free Dictionary. (2011). Free Dictionary. Retrieved January 5, 2018, from 
http://www.thefreedictionary.com/extrinsic

Kompas Gramedia. (2016). History Of Kompas Gramedia. Retrieved January 5, 2018, from http://www.kompasgramedia.com/about-kg/history

Rahadi, F. (2015). Industri Buku Bertahan di Tengah Gempuran Digital. Retrieved February 13, 2018, from http://republika.co.id/berita/pendidikan/eduaction/15/08/15/nt4cot354industri-buku-bertahan-di-tengah-gempuran-digital

Oxford Dictionaries. (2018). Definition of artefact in English by Oxford Dictionaries. Retrieved February 10, 2018, from https://en.oxforddictionaries.com/definition/artefact\%0Ahttps://en.oxforddictionaries.co $\mathrm{m} /$ definition/race 